\title{
Determination of Fluoride and Chloride Contents in Drinking Water by Ion Selective Electrode
}

\author{
Amra Bratovcic and Amra Odobasic \\ University of Tuzla, Faculty of Technology, \\ Bosnia and Herzegovina
}

\section{Introduction}

The fluoride element is found in the environment and constitutes $0.06-0.09 \%$ of the earth's crust. Fluoride is not found naturally in the air in large quantities. Average concentration of fluoride in air are in the magnitude of $0.5 \mathrm{ng} / \mathrm{m}^{3} .{ }^{1}$ ] Fluoride is found more frequently in different sources of water but with higher concentrations in groundwater due to the presence of fluoride-bearing minerals. Average fluoride concentrations in see water are approximately $1.3 \mathrm{mgL}^{-1}$. Water is vitally important to every aspect of our lives. Water is a risk because of the possible input and transmission of infectious pathogens and parasitic diseases. We use clean water to drink, grow crops for food and operate factories. The most common pollutants in water are chemicals (pesticides, phenols, heavy metals and bacteria). [2] According to the US Environmental Protection Agency, there are 6 groups which cause contamination of drinking water: microorganisms, disinfectants, disinfection byproducts, inorganic chemicals, organic chemicals, radioactive substances. This chapter concerns the importance of continuously monitoring of fluoride and chloride in drinking water by using a fluoride (F-ISE) and chloride (Cl-ISE) ion-selective electrodes.

Disinfectants that are added to reduce the number of microorganisms, as well as disinfection byproducts can cause a series of disorders in body (anaemia, impaired function of liver, kidneys, nervous system). Chemical disinfection is economically most favourable when it comes to processing large amounts of water, for the preparation of drinking water and wastewater treatment. That is why this type of disinfection is used almost exclusively in Bosnia and Herzegovina. Chlorine is one of the most widely used disinfectants. Water monitoring information helps us to control pollution level. In this context, our work concerns the determination of fluoride in spring waters from different villages in Tuzla's Canton in Bosnia and Herzegovina, and chloride in drinking tap water from Tuzla and Gradacac as well as one sample of bottled water. Spring water sample from "Tarevcica" is designed by SW1, from "Zatoca" by SW2, from "Sedam vrela" by SW3 and "Toplica" by SW4 while a tap water from Tuzla by TW and tap water from Gradacac by GW and bottled water by FW.

The development of potentiometric ion-selective electrode has a wide range of applications in determining ions in water and other mediums. These electrodes are relatively free from interferences and provide a rapid, convenient and non-destructive means of quantitatively determining numerous important anions and cations. [3] The use of ion-selective electrodes 
enables the determination of very low concentrations of desired ions (to $10^{-6} \mathrm{~mol} \mathrm{~L}^{-1}$ ). The amount of fluoride present naturally in non-fluoridated drinking water is highly variable, being dependent upon the individual geological environment from which the water is obtained. It is well known that fluoridation of drinking water is an important tool in the prevention of tooth decay. Adequate fluoride ingestion is helpful to avoid caries, but over ingestion induces dental and skeletal fluorosis, which may result in malfunction of the bone and joint system. $\left[{ }^{4,5}\right.$. The severity depends upon the amounts ingested and the duration on intake. Dental fluorosis is a condition where excessive fluoride can cause yellowing of teeth, white spots and pitting or mottling of enamel. Skeletal fluorosis is a bone disease exclusively caused by excessive consumption of fluoride.

The procedures of determination of fluoride and chloride will be described in detail. Moreover, it will be discussed advantages and disadvantages of this method. These spring waters are in used for tap water supply. The average fluoride concentration in 4 different fresh spring waters was in a range of 0.04 to $0.12 \mathrm{mg} \mathrm{L}^{-1}$. The fluoride concentrations obtained from the analyses of samples were compared with the permissible values given by the Environmental Protection Agency, World Health Organization, American Dental Association as well as Agency for safety food of Bosnia and Herzegovina who defined maximum amount that is allowed in drinking water. The average chlorine concentration in examined tap water was in a range of $4.55 \mathrm{mg} \mathrm{L}^{-1}$.

\section{Importance of fluoride and chloride content in water}

Chlorine and fluor are very reactive elements and because of that they easily bind to the other elements. They belong to the group of halogens. Fluoride (F-) is an important anion, present in water, air and food. Fluorides come naturally into water by dissolving minerals that contain fluor, such as fluorite $\left(\mathrm{CaF}_{2}\right)$, cryolite $\left(\mathrm{Na}_{3} \mathrm{AlF}_{6}\right)$ and fluorapatite $\left(\mathrm{Ca}_{5}\left(\mathrm{PO}_{4}\right)_{3} \mathrm{~F}\right)$. Rocks rich in alkali metals have a larger content of fluoride than other volcanic rocks. Small amounts of fluoride are vital for the human organism, but it's toxic in larger amounts. Fluoride levels in surface waters vary according to geographical location and proximity to emission sources. Surface water concentrations generally range from 0.01 to $0.3 \mathrm{mg} \mathrm{L}^{-1}$ (ATSDR, 1993). Fluoride in drinking water is generally bioavailable. It has been shown, that with all the human exposure to fluoride that varies from region to region, drinking water is the largest single contributor to daily fluoride intake.[6] Due to this fact, daily fluoride intakes $(\mathrm{mg} / \mathrm{kg}$ of body weight are based on fluoride levels in the water and water consumption per day per litter). There are maximum guiding values for fluoride in drinking water. There are no minimum imposed limits, however there are recommended values to ensure no potential health risks from lack of fluoride within the drinking water. World Health Organisation (WHO) places international standards on drinking water that should be adhered to for health purposes, however is not enforceable and each individual nation may places its own standards and conditions on drinking water. This can be seen in the United States, where the Environmental Protection Agency (EPA) places more lenient drinking water standards than that of the WHO. This can be seen in the table 1 .

Primary drinking water standards are those that must be enforced. Secondary drinking water standards are non-enforceable guidelines regulating contaminants that may cause cosmetic effects (such as skin or tooth discoloration) or aesthetic effects (such as taste, odour or colour) in drinking water.[ 7 ] The WHO maximum guideline value of 1.5 is higher than the recommended value for artificial fluoridation of water supplies, which is usually $0.5-1.0 \mathrm{mgL}^{-1}$. [1] 
Fluoride guideline value
drinking water standards

WHO

USA

Primary

Secondary

ADA

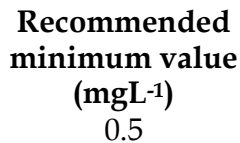

0.5

0.5

0.7

$\underset{\left(\mathrm{mgL}^{-1}\right)}{\operatorname{Maximum} \text { Value }}$

4.0

2.0

1.2

1.5

\section{Reference}

WHO, 1993

US EPA, 1985

Statute, 2007

Agency for Safety Food, B\&H

Table 1. International and national drinking water standards of fluoride contents

Determination of chloride ions is important in many different fields such as clinical diagnosis $[8,9]$ environmental monitoring $[10,11,12]$ and various industrial applications $[13,14]$. Considering the fact that chloride channels play crucial role in physiological processes it is not surprising that missregulation of chloride ions transport by these channels can cause serious disorders. One of disease is cystic fibrosis. [15]

Chloride ions in large quantities are present in sea water and sediments of the Earth's crust where it is associated with ions $\mathrm{Na}^{+}, \mathrm{K}^{+} ; \mathrm{Mg}^{2+}$. Chlorides are widely distributed in nature as salts of sodium $(\mathrm{NaCl})$, potassium $(\mathrm{KCl})$, and calcium $\left(\mathrm{CaCl}_{2}\right)$. Chlorides are leached from various rocks into soil and water by weathering. Exposure to chloride in air has been reported to be negligible. [16] The taste threshold of the chloride anion in water is dependent on the associated cation. Taste thresholds for sodium chloride and calcium chloride in water are in the range $200-300 \mathrm{mg} /$ litre [17]. Sodium chloride is widely used in the production of industrial chemicals such as caustic soda, chlorine, sodium chlorite, and sodium hypochlorite. In the human body it is also found in the form of chloride. In humans, $88 \%$ of chloride is extracellular and contributes to the osmotic activity of body fluids. The electrolyte balance in the body is maintained by adjusting total dietary intake and by excretion via the kidneys and gastrointestinal tract. A normal adult human body contains approximately $81.7 \mathrm{~g}$ chloride. On the basis of a total obligatory loss of chloride of approximately $530 \mathrm{mg} /$ day, a dietary intake for adults of $9 \mathrm{mg}$ of chloride per $\mathrm{kg}$ of body weight has been recommended (equivalent to slightly more than $1 \mathrm{~g}$ of table salt per person per day). For children up to 18 years of age, a daily dietary intake of $45 \mathrm{mg}$ of chloride should be sufficient. [16] A dose of $1 \mathrm{~g}$ of sodium chloride per $\mathrm{kg}$ of body weight was reported to have been lethal in a 9-week-old child [18] Daily requirements for intake of chloride are up to the age range, from newborn to $500 \mathrm{mg}$ and to $2000 \mathrm{mg}$ for adults. Chlorination as a method of water purification is used in $99 \%$ cases of the disinfection of municipal water. The chlorine can be added directly into the water. The taste of chlorinated water could be slightly acidic and it is probably because of the presence of chlorine is in the form of hypochloric acid. Permissible concentration of chlorine as a means of disinfections is up to $3 \mathrm{mg} / \mathrm{L}$. Numerous analytical methods for chloride ions in a variety of samples have been developed, such as ion chromatography $\left[19,{ }^{20}\right]$ near-infrared spectrometry [21] spectroscopy [22] light scattering [23] ionselective electrode method $[13,24,25]$ turbidimetric method $\left.{ }^{26}\right]$ and flow based methods coupled with different detectors $[27,28,29]$.

\section{Potentiometric analysis}

The potentiometric method is based upon measurements of the potential that measures electromotive force of a galvanic element. Direct potentiometric determinations are almost always performed using ion selective electrodes (ISEs), which are capable of rapid and 
selective measurements of analyte concentration. Ion-selective potentiometry (ISP) is a nondestructive method, which means that the sample can be used for further analysis. Ionselective electrode (ISE) such as chloride or fluoride, which is used in our investigation, as detector provides a range of possibilities in the analysis of samples of biological material. [30] Work of ion-selective electrode is based on the fact that there is a linear relationship between the electrical potential established between the ISE and reference electrode and the logarithm of activity (or effective concentration) of ions in the solution. This relationship is described by Nernst equation:

$$
\mathrm{E}=\mathrm{E}^{\circ}+\frac{2,303 \mathrm{RT}}{\mathrm{zF}} \log (\mathrm{a})
$$

where $\mathrm{E}$ is the total potential in $\mathrm{mV}$ developed between the sensing and reference electrode, $\mathrm{z}$ is the ion charge which is negative for anions, $\log (\mathrm{a})$ is the logarithm of the activity of the measured ion. The factor $2,303 \mathrm{RT} / \mathrm{F}$ has a theoretical value of $59 \mathrm{mV}$ at $25^{\circ} \mathrm{C}$. The equation is valid for very dilute solutions or for solutions were the ion strength is constant. The activity is equivalent to the concentration in dilute solutions but becomes increasingly lower as the ionic strength increases. The activity (a) represents the effective concentration, while the total fluoride ion concentration may include some bound ions as well. The electrode responds only to free ions so it is important to avoid the formation of complexes that are meant to be measured. In this case, the complexation would lower the activity and therefore the electrode response. This is effectively the equation of a straight line:

$$
y=m x+c
$$

where $\mathrm{y}=\mathrm{E}=$ the measured electrode response in $\mathrm{mV}, \mathrm{x}=\log (\mathrm{a}), \mathrm{c}=\mathrm{E}^{\circ}=$ the intercept on the $y$ axis, $m=-0,0592 / z=$ the electrode slope.

Ion selective electrodes are available for measuring more than 20 different cations for instance $\mathrm{Ag}^{+}, \mathrm{Na}^{+}, \mathrm{K}^{+}, \mathrm{Ca}^{2+}$, and anions such as $\mathrm{F}^{-}, \mathrm{Cl}^{-}, \mathrm{S}^{2-}, \mathrm{CN}^{-}$.

The function of ion-selective electrode is based on selective leakage of positively charged specie from one phase to another, creating a difference in potential. Working principle is based on measuring the electrode potential $(\mathrm{mV})$ depending on the concentration of tested ions in the solution. The reference electrode has a constant potential, and potential of ISE is changing with the concentration of certain ions.

\subsection{Ion selective electrode as an efficient tool for monitoring of desired ion}

An ion selective electrode is sensitive to analyte concentration due to the properties of the ion-selective membrane that provides the interface between the ion-selective electrode and the sample solution. The ability of the ion selective membrane to conduct current depends in some manner on the presence of analyte in the solutions on both sides of the membrane. The mechanism of this dependence varies but usually depends on some reaction of analyte at the surface of the membrane. Analysis were carried out using a MICROPROCESSOR $\mathrm{pH} /$ ION METER pMX 3000 WTW equipped with a reference electrode WTW R 500 and the F 500 and $\mathrm{Cl} 500$ as an ion-selective electrode. In Figure 1 is schematically shown reference electrode and an ion selective electrode, where 1 indicate the filling opening for the bridge electrolyte, fluid level of the bridge electrolyte, 3 the inner junction which must be covered with bridge electrolyte and 4 the ground junction which indicate the minimum depth of immersion. 


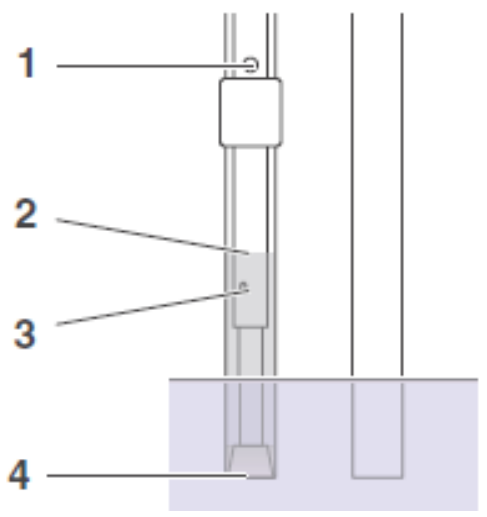

Fig. 1. Schematic representation of reference and an ion-selective electrode. In this picture 1 indicate the filling opening for the bridge electrolyte, 2 - fluid level of the bridge electrolyte, 3 the inner junction which must be covered with bridge electrolyte and 4 - the ground junction.

For measurements with the $\mathrm{F} 500$ fluoride electrode and $\mathrm{Cl} 500$ chloride electrode, a reference electrode is required. In our investigation has been used R 500 as a reference electrode. The two electrodes together form a double rod combination electrode. Ion selective electrodes have been storage into diluted aqueous standard solution. Measuring range for fluoride electrode is $0.02 \mathrm{mg} \mathrm{L}^{-1}$ or $10^{-6} \mathrm{~mol} \mathrm{~L}^{-1}$ and for chloride electrode from 2 to $35000 \mathrm{mg} \mathrm{L}^{-1}$ or from $10^{-5}$ to $1 \mathrm{~mol} \mathrm{~L}^{-1}$.

There are many advantages to use an ion-selective electrode as means of analysis, including its efficiency, selectivity, ease of sample preparation and lack of interference and reactivity with sample itself.

\subsubsection{Fluoride electrode}

One of the most significant of the solid - state electrode is the lanthanum fluoride electrode. The membrane consists of a slice of a single crystal of lanthanum fluoride that has been doped with europium (II) fluoride to improve its conductivity. The membrane, supported between a reference solution and the solution to be measured, shows a theoretical response to changes in fluoride ion activity from 0 to $10^{-6} \mathrm{~mol} \mathrm{dm}^{-3}$. The electrode is selective for fluoride ion, only hydroxide ion appears to offer serious interference.[31] The unique property of a europiumdoped lanthanum fluoride crystal to form a membrane apparently permeable to fluoride ion and virtually no other anion or cation, provided the first specific ion - selective fluoride electrode. This electrode gives Nerstian response to fluoride ion concentrations from above $1 \mathrm{M}$ to below $10^{-5} \mathrm{M}$, and only $\mathrm{OH}^{-}$seems to interfere with this response.

Srinivasan and Rechnitz [32] noted that stirring sometimes had a substantial effect on the observed potential. In $10^{-3} \mathrm{M} \mathrm{NaF}$ solution, the potential changed from - $61.5 \mathrm{mV}$ in a quiescent solution to $-55.5 \mathrm{mV}$ in a rapidly stirred solution. This shift was less at high concentrations and negligible in the presence of $0.1 \mathrm{M} \mathrm{NaNO}_{3}$ supporting electrolyte, even at fluoride concentration as low as $5 \times 10^{-5} \mathrm{M}$. They recommended that readings be taken with slow stirring (by a Teflon - coated magnetic bar), and that under these conditions reproducibility was excellent: "The potentials were found to be quite stable, changing not more than $0.1 \mathrm{mV}$ even after an hour. The reproducibility on the same day for two different solutions of the same concentration was within $0.1 \mathrm{mV}^{\prime \prime}$. 
The kinetic response of the electrode is almost instantaneous [32, 33], limited by the recorder response time of $0.5 \mathrm{sec}$, at least in the solutions containing fluoride concentrations greater than millimolar. In very dilute solutions, the response time is has been reported to be very long.

\subsubsection{Chloride electrode}

The chloride ion-selective electrode is a polycrystalline solid-state electrode that contains a membrane. The membrane consists of a solid salt of silver sulfide/silver chloride. The membrane must be insoluble in the analyte solution and contain the analyte ion of interest. The membrane is placed at the end of a solid plastic tube. This membrane is in contact with the analyte solution during the measurement. Inside of the tube is a reference solution, which contains a known and fixed concentration of analyte $(\mathrm{Cl}-)$ solution. The concentration difference between this inner solution and analyte solution causes the migration of charged species across the membrane. This ion exchange process at the surface of the membrane causes a potential to develop. Since the potential of both the reference electrode and the inner reference (immersed in the standard solution) are constant, any change in measured potential is caused only by a change in potential across the membrane and is a function of the analyte chloride ion activity (or concentration).

The electrode is designed to detect chloride ions in aqueous and viscous solutions and is suitable for use in laboratory investigations. The method allows the determination of chloride in treated water, natural water, drinking water and most waste water with high accuracy and sensitivity. The method is applicable only to samples containing more than $10000 \mathrm{mgL}^{-1}$ dissolved substances.

All reagents used were of analytical reagent grade and were used without further purification.

\section{Results}

In the experimental work ISP as a choice method was used, and Mohr's method as a standard was the control method for the determination of chloride ions in drinking tap water. As a comparative method could be use the UV/vis spectrophotometric method with zirconium (IV) ion oxychloride and alizarin $S$ for analysis of Fluoride contents. For the determination of chloride and fluoride ions in represented drinking water has not been required previously sample pre-treatment. Quantitative analyses were performed with calibration curves obtained with standard solutions. The calibration curve has been constructed by plotting obtained electrode potential vs. logarithm of concentrations of standard chloride and fluoride solutions. In our experiments, several standard solutions with different concentrations were prepared. Then, we measured the cell potential for each individual standard solution and plot $\mathrm{E}_{\mathrm{cell}}$ vs. $\log \mathrm{C}_{\mathrm{F}-}$. This curve is our calibration curve and has been used to determine the concentration of the unknown. The F-ISE method for the fluoride determination can be applied either without pretreatment technique, namely conventional potentiometric method, or with pretreatment technique, such as coprecipitation and steam distillation. Frant and Ross ${ }^{[34]}$ pointed out that there were changes in potential as the $\mathrm{pH}$ of fluoride solutions was changed.

Since ion-selective electrode responds to activity of the analyte, it is extremely important ionic strength solution. From the literature it is known that the $\mathrm{OH}$-ions are only interfering ions for fluoride electrode, at $\mathrm{pH}$ greater than eight. However, at $\mathrm{pH}$ lower than five, the hydrogen ions also interfere, but the $\mathrm{pH}$ can not be too low due to the formation of $\mathrm{HF}$, 
which is a weak acid and whose salt with water gives alkaline reaction. The interference for this fluoride electrode is $\mathrm{pH}$ less than 5 and higher than 7.

In this work has been used the electrode without the addition of any ionic buffer for the determination of $\mathrm{F}^{-}$in examined water. The composition of the water and the total ionic strength were analysed and were not over allowable limit for this methods in a range of allowed concentration. The interference on the fluoride electrode from hydroxyl ion $\left(\mathrm{OH}^{-}\right)$is eliminated by ensuring that $\mathrm{pH}$ is kept below 8 . Consequently, there was no necessity to add TISAB buffer to ensure constant ionic strength.

\section{Experimental part}

\subsection{Potentiometric determination of fluoride}

A $1000 \mathrm{mg} \mathrm{L}^{-1}$ sodium fluoride stock solution was prepared by dissolving 2,21 g NaF in a $1000 \mathrm{~mL}$ polystyrene volumetric flask with deionised water. Sodium fluoride has been previously oven-dried at $105{ }^{\circ} \mathrm{C}$ for 1 hour and stored in a dessicator. The concentration of this stock solution is $1000 \mathrm{mgL}^{-1}$. Standards at the required concentration were prepared by appropriate dilution of the stock solution.

Calibration diagrams were obtained by measuring of potential of six different sets of fluorid standard solutions ordered from low to high concentration. The concentration range is from 0.07 to $1.0 \mathrm{mgL}^{-1}$. The meter reading was taken after a constant value has been attained that is drift $<0,1 \mathrm{mV} / \mathrm{min}$. The results are given in Table 2 .

$\begin{array}{ccccccc}\text { Concentration of } \mathrm{F}^{-}\left(\mathrm{mgL}^{-1}\right) & 0.07 & 0.1 & 0.3 & 0.5 & 0.7 & 1.0 \\ \text { Log } \mathrm{F}_{\mathrm{F}^{-}} & -1,154 & -1,0 & -0,522 & -0,301 & -0,154 & 0.0 \\ \text { Potential }(\mathrm{mV}) & 33,6 & 21,3 & -0,1 & -12,2 & -24,7 & -31,5\end{array}$

Table 2. Potentiometric responses of the membrane towards different concentrations of fluoride ion.

On the basis of these results has been constructed diagram 1 .

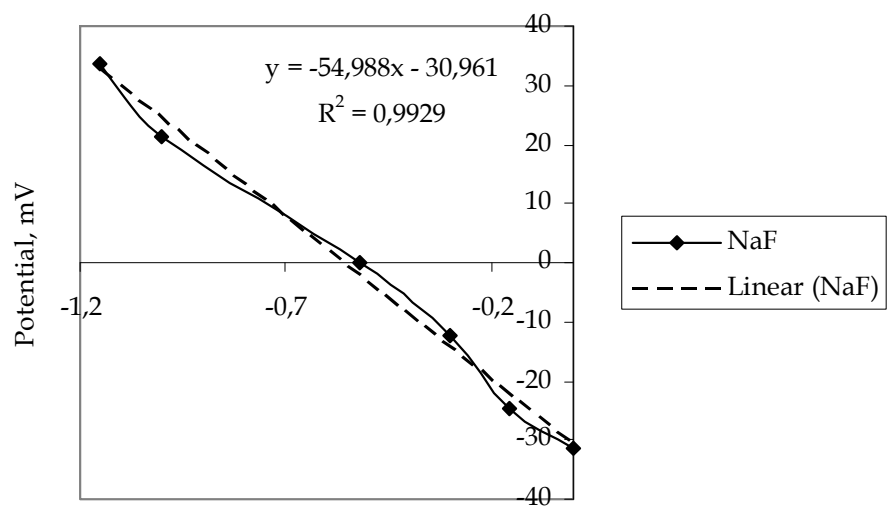

Log Conc. of Fluoride

Diagram 1. Calibration curve for Fluoride ISE obtained for fluoride standard solutions in range of concentration from 0,07 to $1 \mathrm{~mol} \mathrm{~L}^{-1}$. This calibration graph has been used for determination of the samples marked as SW1, SW2, SW3 and SW4. 
For determining the concentration of F-ions, the samples were placed in a clean, dry glass in quantities of $50 \mathrm{ml}$. [35] First of all, has been determined the $\mathrm{pH}$ of the sample. The measured $\mathrm{pH}$ value was in the range from 5 to 7 , and then the sample has been stirred by using a magnetic stirrer for 5 minutes. After that, it has been measured the concentration of fluoride ions, by immersion of the reference and fluoride ion-selective electrode connected to the ionmeter. After a few minutes were read values of the potential. Each sample was measured three times in order to reduce experimental error. Based on the measured potential, was calculated the concentration of fluoride for each individual measurement, and then, calculated the average value of concentration.

In Table 3 are represented the obtained concentrations in samples marked as SW1, SW2, SW3 and SW4.

$\begin{array}{ccccc}\text { Sample } & \text { SW1 } & \text { SW2 } & \text { SW3 } & \text { SW4 } \\ \text { Potential }(\mathrm{mV}) & 44,5 & 47,1 & 36,5 & 18,7 \\ \text { Conc. F- }\left(\mathrm{mgL}^{-1}\right) & 0,042 & 0.038 & 0.059 & 0.12\end{array}$

Table 3. Concentrations of fluoride obtained for samples: SW1, SW2, SW3 and SW4.

For these samples also have been determined the concentration of chloride by mercurimetric titration. The results are shown in table 4.

$\begin{array}{cc}\text { Sample } & \text { Concentration of Chloride }\left(\mathrm{mgL}^{-1}\right) \\ \text { SW1 } & 2,81 \\ \text { SW2 } & 4,80 \\ \text { SW3 } & 3,60 \\ \text { SW4 } & 7,25\end{array}$

Table 4. Concentrations of chloride obtained by mercurimetric titration method.

\subsection{Potentiometric determination of chloride}

Specific ion electrodes measure activity and not concentration, a large amount of an inert strong electrolyte (e.g. nitrate ion) can be added to fix the ionic strength to a constant value. When the ionic strength is constant, the activity is constant and concentration can be accurately measured. To determine the concentration of chloride ions, samples were prepared as follows: in a glass flask of $100 \mathrm{ml}$ was measured $2 \mathrm{ml}$ of $5 \% \mathrm{NaNO}_{3}$, and diluted to mark with water that is being analyzed $\left(5 \% \mathrm{NaNO}_{3}\right.$ concentrations in all samples was 0.1 mol L-1). Then, $5 \mathrm{~mL}$ of prepared sample was transferred in clean, dry glass and stirred using a magnetic stirrer for 5 min with immersed electrodes. After 5 minutes of stirring, the magnetic stirrer has been stopped and then red the potential. Response time for all samples was in a range from 1 to 5 minutes. The samples marked by FW, TW and GW have been analyzed on chloride concentration using a chloride selective electrode. The sample designed as FW was analyzed using a calibration curve represented in diagram 2, while the samples marked as TW and GW by using a calibration curve shown in diagram 3 . In Table 5 are given the concentration of chloride solutions for KK1 calibration curve.

$\begin{array}{cccccc}\text { Conc. } \mathrm{Cl}^{-}\left(\mathrm{mgL}^{-1}\right) & 60 & 120 & 180 & 230 & 280 \\ \text { Potential }(\mathrm{mV}) & 155.1 & 148.6 & 143.7 & 140.2 & 135.3\end{array}$

Table 5. Electrode response on prepared chloride standard solutions. 


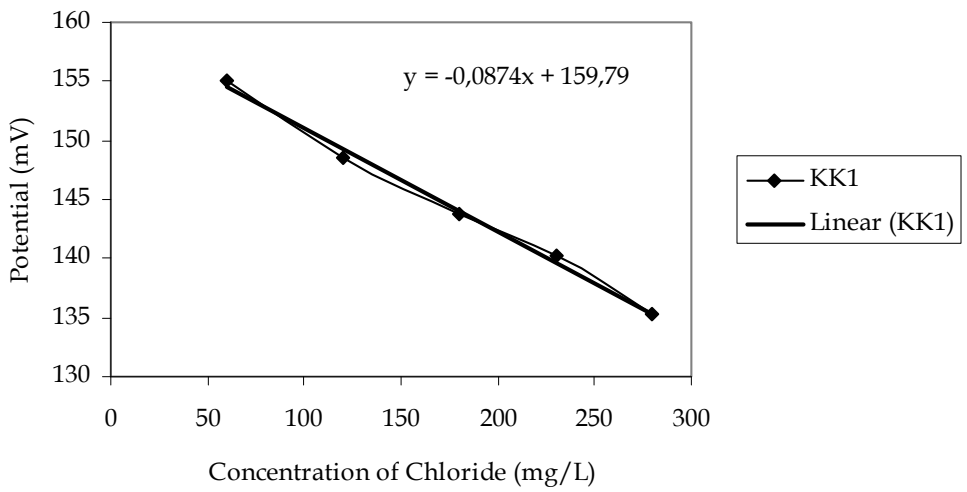

Diagram 2. Shows the obtained calibration curve KK1.

In Table 6 are given the concentration of chloride solutions for KK2 calibration curve.

$\begin{array}{lllllll}\text { Conc. } \mathrm{Cl}^{-}\left(\mathrm{mgL}^{-1}\right) & 1 & 3 & 5 & 10 & 15 & 20 \\ \text { Potential }(\mathrm{mV}) & 183.3 & 179.6 & 177.8 & 171.5 & 166.8 & 161.3\end{array}$

Table 6. Electrode response on prepared chloride standard solutions.

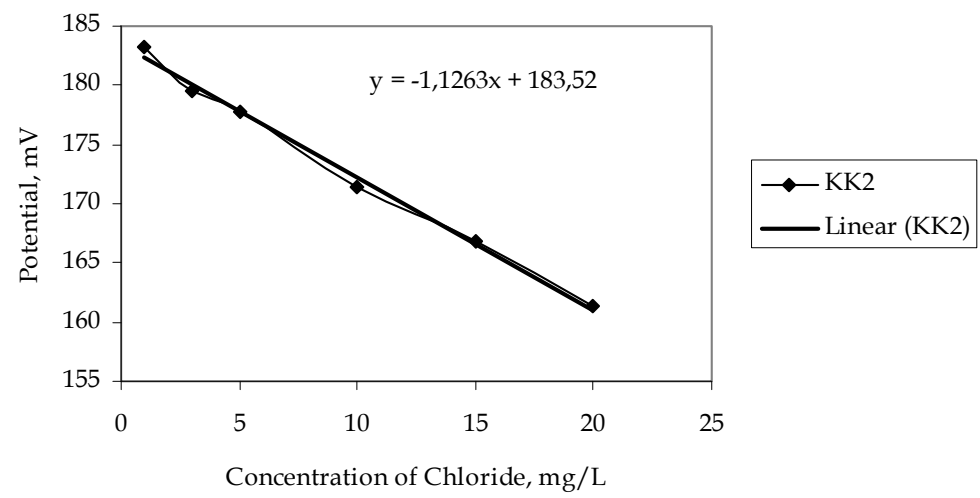

Diagram 3. Shows the obtained calibration curve KK2.

In Table 7 are shown the average concentrations of chloride ion determined in our tested samples.

$\begin{array}{lccc}\text { Sample } & \text { FW } & \text { TW } & \text { GW } \\ \text { Potential, mV } & 129.9 & 171,9 & 178,4 \\ \text { Concentration, mg/L } & 341.99 & 10,12 & 4,55\end{array}$

Table 7. Concentrations of chloride obtained for samples: FW, TW and GW determined using appropriate calibration curve. 


\subsection{Mohr's method}

Cations and anions are systematized according to the analytical groups to make it easier to prove. When the sample contains a lot of cations and anions is difficult or even impossible to prove, because they interfere with each other. Ions belonging to a different groups defined by their relationship to reagent with which the ion is deposited in hard soluble salt. Chloride ion belongs to the fourth group of anions that precipitate reagent $\mathrm{AgNO}_{3}$. Mohr's method is used for volumetric determination of chloride by titration with $\mathrm{AgNO}_{3}$ solution in neutral or slightly alkaline solution and using of potassium or sodium chromate as indicator. It is based on the reactions of the formation of hardly soluble precipitates with the condition that the reaction of precipitation is fast and that there is a true indicator that shows the end of the titration. To determine the concentration of chloride by Mohr, samples were prepared as follows: the sample has been transferred by pipette of $25 \mathrm{~mL}$ into Erlenmayer flask and diluted by distilled water (about $100 \mathrm{~mL}$ ) and added $2 \mathrm{~mL}$ of $5 \% \mathrm{~K}_{2} \mathrm{CrO}_{4}$. Thus, titration of the sample prepared in this way has been done with standard solution of 0,0984 mol/L $\mathrm{AgNO}_{3}$. The standardization of $\mathrm{AgNO}_{3}$ has been done previously. Titration was completed when appeared a reddish solution.

The amount of chloride was calculated using the equation:

$$
m_{\mathrm{Cl}^{-}}=\mathrm{C}_{\mathrm{AgNO}_{3}} \cdot V_{\mathrm{AgNO}_{3}} \cdot \mathrm{M}_{\mathrm{Cl}} \cdot \mathrm{R}
$$

where:

$\mathrm{m}_{\mathrm{Cl}}$ - the amount of chloride in water $(\mathrm{g})$

$\mathrm{C}_{\mathrm{AgNO} 3}$ - concentration of solution ( $\left.\mathrm{mol} \mathrm{L}^{-1}\right)$

$\mathrm{V}_{\mathrm{AgNO} 3}$ - volume of $\mathrm{AgNO}_{3}$ used for titration (L)

R- dilution

Calculated values of chloride concentration by Mohr method is $14.8 \mathrm{mg} \mathrm{L}^{-1}$ for TW sample. TW sample shows a significant discrepancy in values between the two methods used. The difference is caused by problems that can occur when working with a chloride electrode. Interference can cause:

- $\quad$ Complexes with $\mathrm{Bi}^{3+}, \mathrm{Cd}^{2+}, \mathrm{Mn}^{2+}, \mathrm{Pb}^{2+}, \mathrm{Sn}^{2+}, \mathrm{Tl}^{2+}$

- $\quad$ Reducing agents

- Interfering ions: $10 \%$ error with the following concentration ratio.

(concentration ratio $=$ interfering ion/measured ion):

In the table are given values of concentration relations for some interfering ions:

\begin{tabular}{|c|c|c|c|c|c|c|}
\hline $\mathrm{OH}^{-}$ & $\mathrm{Br}^{-}$ & $\mathrm{J}^{-}$ & $\mathrm{S}^{2-}$ & $\mathrm{CN}^{-}$ & $\mathrm{NH}_{3}$ & $\mathrm{~S}_{2} \mathrm{O}_{3}^{2-}$ \\
\hline 80 & $3 \times 10^{-3}$ & $5 \times 10^{-3}$ & $1 \times 10^{-6}$ & $2 \times 10^{-7}$ & 0.12 & 0.01 \\
\hline
\end{tabular}

To determine accurately interfering ion present and its concentration in the sample, TW, require long and detailed chemical and bacteriological analysis of water. The results obtained for the GW and TW indicate that the chloride content is in the range of permissible limits prescribed by WHO.

Results for the FW sample show that the concentration of chloride ions is extremely high and exceeds the maximum limit. According to the Regulations of the Republic of Serbia, given that Bosnia and Herzegovina has no defined Rules on allowable concentrations of cations and anions in water, for the chloride limit is $200 \mathrm{mgL}^{-1}$ (Official Gazette of SFRY 42/98). The limit in drinking water is $250 \mathrm{mgL}^{-1}$. European Economic Community 
Directive 80/777/EEC provides that in case of bottled natural mineral waters, chloride concentrations exceed $200 \mathrm{mgL}^{-1}$, and then the water is declared on the label as chlorinated.

\section{Conclusion}

Electroanalytical methods based on potentiometry with ion-selective electrodes seem to be the most popular and convenient methods of fluoride and chloride ion determination. Fluoride and chloride selective electrodes can be used to determine fluoride and chloride concentrations in drinking water due to its high selectivity, specificity and low detection limits. The advantages of this study include a short analysis time, elimination of sample pretreatment, simplicity of the measuring system and relatively low instrument cost. The concentration of fluoride ion was determined in 4 drinking water samples, while the concentrations of chloride have been determined in 3 samples (FW, TW and GW) by a chloride selective electrode as well as by Mohr's method. All these samples were analyzed with use direct reading method. By our experimental data we can conclude that the concentration of fluoride in samples marked as SW1, SW2, SW3 and SW4 is within allowed concentration according to World Health Organisation. On the basis of the results of analysis carried out on the water content chloride ions can be concluded that the applied electrochemical measurements and analytical shown that the content is the same within the limits of permissible concentration laid down by WHO. Method ISP when it proved more effective, fast and reliable enough to determine chloride ions in the water and the concentration in the range of $10^{-4} \mathrm{~mol} \mathrm{~L}^{-1}$ to $10^{-5} \mathrm{~mol} \mathrm{~L}^{-1}$. Additionally, it has an advantage over any other analytical method because it is non-destructive and allows the use of samples for other types of analysis. Based on the results obtained it can be concluded that there are many advantages of using ion-selective potentiometry (ISP) in reference to standard spectrophotometric and Mohr's methods, because measurements with the ISP are faster, efficient and reliable. It does not require the use of many different chemicals, and does not require any preparation of samples before analysis, which directly affects the economic availability. Our experimental data give in evidence that the concentration in these samples are within the allowed concentration according to World Health Organisation except the concentration of chloride in tested bottled water. Therefore, determining of Fluoride and Chloride in drinking water is of great significance for human health because of daily consumption of certain amounts.

\section{References}

[1] Fluoride in Drinking - water, WHO, 2004.

[2] Rowell, R. M.; Removal of metal ions from contaminated water using agricultural residues, $2^{\text {nd }}$ International Conference on Environmentally - Compatible Forest Products, Portugal (2006), 241-250.

[3] Hutchins, R. S.; Bachas, L. G.; In: Handbook of Instrumental Techniques for Analytical Chemistry, (Ed.), Chapter 38, 727-748, Upper Saddle River, NJ: Prentice-Hall, 1997.

[4] Institute of Medicine, (1997), Fluoride. In "Dietary reference intakes for calcium, phosphorus, magnesium, vitamin D, and fluoride", 288-313. National Academy Press. Washington, D.C., U.S.A.

[5] World Health Organisation (WHO) 2002, Fluorides, World Health Organization (Environmental Health Criteria 227). 
[6] Appropriate use of fluorides for human health, J. J. Murray, 1986.

[7] United States Environmental Protection Agency (US EPA), 1985.

[8] Jiang, Q.S.; Mak, D.; Devidas, S.; Schwiebert, E.M.; Bragin, A.; Zhang, Y.L.; Skach, W.R.; Guggino, W.B.; Foskett, J.K.; Engelhardt, J.F., J. Cell Biol. 1998, 143, 645-657.

[9] Huber, C.; Werner, T.; Krause, C.; Klimant, I.; Wolfbeis, O.S., Anal. Chim. Acta 1998, 364, 143-151.

[10] Montemor, M.F.; Alves, J.H.; Simoes, A.M.; Fernandes, J.C.S.; Lourenco, Z.; Costa, A.J.S.; Appleton, A.J.; Ferreira, M.G.S., Cem. Concr. Compos. 2006, 28, 233-236.

[11] Huber, C.; Klimant, I.; Krause, C.; Werner, T.; Mayr, T.; Wolfbeis, O.S., Fresenius J. Anal. Chem. 2000, 368, 196-202.

[12] Martin, A.; Narayanaswamy, R., Sens. Actuator B-Chem. 1997, 39, 330-333.

[13] Babu, J.N.; Bhalla, V.; Kumar, M.; Mahajan, R.K.; Puri, R.K., Tetrahedron Lett. 2008, 49, 2772-2775.

[14] Badr, I.H.A.; Diaz, M.; Hawthorne, M.F.; Bachas, L.G., Anal. Chem. 1999, 71, 1371-1377.

[15] Ratjen, F.; Doring, G., Lancet 2003, 361, 681-689.

[16] Department of National Health and Welfare (Canada). Guidelines for Canadian drinking water quality. Supporting documentation. Ottawa, 1978.

[17] RC Weast, ed. CRC handbook of chemistry and physics, 67th ed. Boca Raton, FL, CRC Press, 1986.

[18] Sodium, chlorides, and conductivity in drinking water: a report on a WHO working group. Copenhagen, WHO Regional Office for Europe, 1978 (EURO Reports and Studies 2).

[19] Mesquita, R.B.R.; Fernandes, S.M.V.; Rangel, A., J. Environ. Monit. 2002, 4, 458-461.

[20] Pimenta, A.M.; Araujo, A.N.; Conceicao, M.; Montenegro, B.S.M.; Pasquini, C.; Rohwedder, J.J.R.; Raimundo, I.M., J. Pharm. Biomed. Anal. 2004, 36, 49-55.

[21] Wu, R.H.; Shao, X.G., Spectrosc. Spectr. Anal. 2006, 26, 617-619.

[22] Philippi, M.; dos Santos, H.S.; Martins, A.O.; Azevedo, C.M.N.; Pires, M., Anal. Chim. Acta 2007, 585, 361-365.

[23] Cao, H.; Dong, H.W., J. Autom. Methods Manag. Chem. 2008, Article No 745636, 5.

[24] Kumar, K.G.; John, K.S.; Indira, C.J., Indian J. Chem. Technol. 2006, 13, 13-16.

[25] Shishkanova, T.V.; Sykora, D.; Sessler, J.L.; Kral, V., Anal. Chim. Acta 2007, 587, 247-253.

[26] Mesquita, R.B.R.; Fernandes, S.M.V.; Rangel, A., J. Environ. Monit. 2002, 4, 458-461.

[27] Junsomboon, J.; Jakmunee, J., Talanta 2008, 76, 365-368.

[28] Pimenta, A.M.; Araujo, A.N.; Conceicao, M.; Montenegro, B.S.M.; Pasquini, C.; Rohwedder, J.J.R.; Raimundo, I.M., J. Pharm. Biomed. Anal. 2004, 36, 49-55.

[29] Bonifacio, V.G.; Figueiredo-Filho, L.C.; Marcolino, L.H.; Fatibello-Filho, O., Talanta 2007, 72, 663-667.

[30] Mentus S., Electrochemistry (Belgrade, 2001).

[31] Douglas A. Skoog, Donald M. West, F. James Holler, Stanley R. Crouch, Fundamentals of Analytical Chemistry, $8^{\text {th }}$ edition, pag. 607.

[32] Srinivasan K., Rechnitz G. A., Anal. Chem. 40, 509 (1968).

[33] Srinivasan K., Rechnitz G. A., Anal. Chem. 40, 1818 (1968).

[34] Frant, M., Ross, J. W., Jr., Science 154, 1553 (1966).

[35] Bratovcic A., Master thesis, Determining of Fluoride contents in waters by application of contemporary of electrochemical methods, 2008, Tuzla, Bosnia and Herzegovina. 


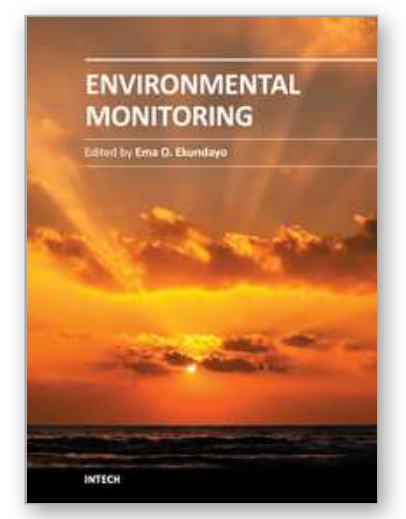

\author{
Environmental Monitoring \\ Edited by Dr Ema Ekundayo
}

ISBN 978-953-307-724-6

Hard cover, 528 pages

Publisher InTech

Published online 04, November, 2011

Published in print edition November, 2011

"Environmental Monitoring" is a book designed by InTech - Open Access Publisher in collaboration with scientists and researchers from all over the world. The book is designed to present recent research advances and developments in the field of environmental monitoring to a global audience of scientists, researchers, environmental educators, administrators, managers, technicians, students, environmental enthusiasts and the general public. The book consists of a series of sections and chapters addressing topics like the monitoring of heavy metal contaminants in varied environments, biolgical monitoring/ecotoxicological studies; and the use of wireless sensor networks/Geosensor webs in environmental monitoring.

\title{
How to reference
}

In order to correctly reference this scholarly work, feel free to copy and paste the following:

Amra Bratovcic and Amra Odobasic (2011). Determination of Fluoride and Chloride Contents in Drinking Water by Ion Selective Electrode, Environmental Monitoring, Dr Ema Ekundayo (Ed.), ISBN: 978-953-307-724-6, InTech, Available from: http://www.intechopen.com/books/environmental-monitoring/determination-of-fluorideand-chloride-contents-in-drinking-water-by-ion-selective-electrode

\section{INTECH}

open science | open minds

\section{InTech Europe}

University Campus STeP Ri

Slavka Krautzeka 83/A

51000 Rijeka, Croatia

Phone: +385 (51) 770447

Fax: +385 (51) 686166

www.intechopen.com

\section{InTech China}

Unit 405, Office Block, Hotel Equatorial Shanghai

No.65, Yan An Road (West), Shanghai, 200040, China

中国上海市延安西路65号上海国际贵都大饭店办公楼405单元

Phone: +86-21-62489820

Fax: +86-21-62489821 
(C) 2011 The Author(s). Licensee IntechOpen. This is an open access article distributed under the terms of the Creative Commons Attribution 3.0 License, which permits unrestricted use, distribution, and reproduction in any medium, provided the original work is properly cited. 